\title{
Interleukin-1 $\beta$ induces intercellular adhesion molecule-1 expression, thus enhancing the adhesion between mesenchymal stem cells and endothelial progenitor cells via the p38 MAPK signaling pathway
}

\author{
JUN GUO $^{1,2}$, HONGWEI ZHANG ${ }^{1}$, JIE XIA ${ }^{1}$, JIXUE HOU ${ }^{1}$, YIXIAO WANG ${ }^{1}$, TAO YANG $^{1}$, \\ SIBO WANG ${ }^{1}$, XUYONG ZHANG ${ }^{1},{\text { XUELIN } \mathrm{CHEN}^{3} \text { and XIANGWEI WU }}^{1,4}$

\begin{abstract}
${ }^{1}$ Department of General Surgery, The First Affiliated Hospital, School of Medicine, Shihezi University, Shihezi, Xinjiang 832008; ${ }^{2}$ Department of Vascular Surgery, People's Hospital of Xinjiang Uygur Autonomous Region,
\end{abstract} \\ Urumqi $830002 ;{ }^{3}$ Department of Immunology, School of Medicine, Shihezi University, Shihezi, Xinjiang 832002; \\ ${ }^{3}$ Laboratory of Translational Medicine, School of Medicine, Shihezi University, Shihezi, Xinjiang 832008, P.R. China
}

Received February 15, 2016; Accepted December 18, 2017

DOI: $10.3892 /$ ijmm.2018.3424

\begin{abstract}
Endothelial progenitor cells (EPCs) are an important component of stem-cell niches, which are able to promote the self-renewal and pluripotency of mesenchymal stem cells (MSCs). The biological functions of these two cell types is dependent on adhesion, and the adhesion between MSCs and EPCs is important due to their critical role in neovascularization and bone regeneration in tissue engineering. Intercellular adhesion molecule-1 (ICAM-1, also known as cluster of differentiation 54), is a member of the immunoglobulin supergene family, which functions in cell-cell and cell-matrix adhesive interactions. Compared with other adhesion molecules, ICAM-1 is expressed in hematopoietic and nonhematopoietic cells, and can mediate adhesive interactions. The present study aimed to investigate the importance of ICAM-1 in the adhesion of MSCs and EPCs, and demonstrated that adhesion between these cells could be regulated by interleukin (IL)- $1 \beta$ via the p38 mitogen-activated protein kinase pathway. In addition, the results confirmed that ICAM-1 served a critical role in regulation of adhesion between MSCs and EPCs. ELISA, cell immunofluorescence, western blot analysis and adhesion
\end{abstract}

Correspondence to: Professor Xiangwei Wu, Department of General Surgery, The First Affiliated Hospital, School of Medicine, Shihezi University, 107 North 2nd Road, Shihezi, Xinjiang 832008, P.R. China

E-mail: wxwshz@126.com

Professor Xuelin Chen, Department of Immunology, School of Medicine, Shihezi University, 107 North 2nd Road, Shihezi, Xinjiang 832002, P.R. China

E-mail: xuelinch@hotmail.com

Key words: mesenchymal stem cells, endothelial progenitor cells, adhesion, stem-cell niche, interleukin-1 $\beta$, intercellular adhesion molecule-1, p38 mitogen-activated protein kinase signaling pathway assay were used to confirm our theory from phenomenon to essence. The present study provided evidence to support and explain the adhesion between MSCs and EPCs. Furthermore, the present findings provide a theoretical basis for further stem-cell niche transplantation to increase understanding of the function of MSCs and the crosstalk between MSCs and EPCs in the stem-cell niche.

\section{Introduction}

Mesenchymal stem cells (MSCs) are multipotent stem cells derived from the bone marrow (BM), which can differentiate into osteoblasts, chondrocytes and adipocytes (1-3). Therefore, MSCs are considered as the most important seed cells for tissue engineering. Maintenance of the self-renewing and multipotent properties of MSCs is regulated by molecular signals from the specific microenvironment where they reside, which is also known as the stem-cell niche (4-6).

Our previous study reported that MSCs exhibit high levels of interaction with cluster of differentiation (CD) $31^{+}$endothelial progenitor cells (EPCs) in the BM microenvironment, thus forming cell clusters in the sinus of the BM cavity (7). Therefore, it was hypothesized that EPCs are a significant component of stem-cell niches, which may promote the self-renewing and multipotent properties of MSCs. EPCs (8-10) reside in niches located in the BM and assist in homeostasis by maintaining vascular function. In addition, combination of EPCs with MSCs has been reported to enhance neovascularization and bone regeneration (11-14). These findings provided a novel basis for clinical bone injury treatment and vascular bone regeneration; however, what mediates the adhesion between MSCs and EPCs, and the underlying molecular mechanism, remain unclear.

Intercellular adhesion molecule-1 (ICAM-1, also known as CD54) is a member of the immunoglobulin supergene family, and functions in cell-cell and cell-matrix adhesive interactions. Compared with other adhesion molecules, ICAM-1 is 
expressed in hematopoietic and nonhematopoietic cells, and can mediate adhesive interactions (15-18). Interleukin (IL)- $1 \beta$ is an important inflammatory mediator that regulates the expression of ICAM-1 (19-21), and serves as a hallmark for bone damage (22-25) and vascular injury $(26,27)$. Therefore, investigating the effects of IL-1 $\beta$ on ICAM-1, and the effects of ICAM-1 on cohesion between MSCs and EPCs may contribute to further understanding of stem-cell niche adhesion. Nevertheless, adhesion is mediated by numerous intracellular signaling pathways. Previous studies have suggested that the p38 mitogen-activated protein kinase (MAPK) pathway has a critical role in the expression of ICAM-1, and IL-1 $\beta$ has been reported to activate the 338 MAPK pathway (28-31). Therefore, the present study hypothesized that the p38 MAPK signaling pathway may be important in the crosstalk between MSCs and EPCs in the stem-cell niche.

\section{Materials and methods}

Animal preparation and cell culture. A total of 24 male C57BL/6J (wild-type) mice (age, 6-8 weeks; weight, 28-35 g) were used to obtain cells for use in the present study. All mice were purchased from Xinjiang Medical University (Ürümqi, China; certificate no. SYXK [Xin] 2010-0001). The mice were maintained in the Animal Facility of the Shihezi University (Shihezi, China) under controlled conditions (temperature, $20^{\circ} \mathrm{C}$; humidity, $55 \pm 5 \%$; 12-h light/dark cycles), with free access to food and water and were used as a cell source. All mice used in the present study were matched for age and gender. Both isolated cell types underwent similar techniques with regards to culture and harvest; however, the media and materials used for culture were different between the cell types. Third generation cells were used for all experiments. All experimental protocols used in the present study were reviewed and approved by the Animal Care and Use Committee of Shihezi University.

Isolation and culture of MSCs and EPCs from murine BM. MSCs and EPCs were isolated from murine BM obtained from the tibia and femur according to our previous study (7). Briefly, mice (C57BL/6J; age, 6-8 weeks) were euthanized by cervical dislocation and BM cells were collected. The cells were cultured in low glucose Dulbecco's modified Eagle's medium (LG-DMEM) supplemented with $10 \%$ lot-selected fetal bovine serum (FBS) (both from Gibco; Thermo Fisher Scientific, Inc., Waltham, MA, USA), $2 \mathrm{mM}$ glutamine, $100 \mathrm{U} / \mathrm{ml}$ penicillin and $100 \mu \mathrm{g} / \mathrm{ml}$ streptomycin (all from Sigma-Aldrich; Merck KGaA, Darmstadt, Germany) at $37^{\circ} \mathrm{C}$ in a humidified incubator containing $5 \% \mathrm{CO}_{2}$ for $48 \mathrm{~h}$ of adhesion. Subsequently, non-adherent cells were collected and cultured in EBM-2 medium (Lonza Group Ltd., Basel, Switzerland) supplemented with $100 \mathrm{U} / \mathrm{ml}$ penicillin and $100 \mu \mathrm{g} / \mathrm{ml}$ streptomycin at $37^{\circ} \mathrm{C}$ in a humidified incubator containing $5 \% \mathrm{CO}_{2}$ for $48 \mathrm{~h}$. In particular, the EPCs were initially plated in a $60 \mathrm{~mm}$ fibronectin (BD Biosciences, Franklin Lakes, NJ, USA) coated cell culture dish to promote cell adhesion and growth. Adherent cells were maintained and the non-adherent cells were removed with medium replacement every $48 \mathrm{~h}$ to form uniform cells. The adherent cells were then retrieved by trypsin digestion supplemented with $0.25 \%$ EDTA (HyClone;
GE Healthcare, Logan, UT, USA) and were incubated at $37^{\circ} \mathrm{C}$ for $30 \mathrm{~min}$ with Sca-1 [-phycoerythrin (PE); cat. no. 108107; $0.2 \mathrm{mg} / \mathrm{ml} ; 1: 50$ ], CD29 [-fluorescein isothiocyanate (FITC); cat. no. $102205 ; 0.2 \mathrm{mg} / \mathrm{ml} ; 1: 50]$, CD45 [-peridinin chlorophyll protein complex (PerCP); cat. no. 202220; $0.2 \mathrm{mg} / \mathrm{ml}$; 1:50] and CD11b [-allophycocyanin (APC); cat. no. 201809; $0.2 \mathrm{mg} / \mathrm{ml} ; 1: 50]$ mouse monoclonal antibodies (BioLegend, Inc., San Diego, CA, USA). The cells underwent flow cytometry and were analyzed using FACSDIVA software version 6.1.3 (both from BD Biosciences). Sorted Sca- $1^{+}$CD29+ CD11b CD45 cells (MSCs) were obtained for further culture in the LG-DMEM supplemented with $10 \%$ lot-selected FBS (both from Gibco; Thermo Fisher Scientific, Inc.), $2 \mathrm{mM}$ glutamine, $100 \mathrm{U} / \mathrm{ml}$ penicillin and $100 \mu \mathrm{g} / \mathrm{ml}$ streptomycin (all from Sigma-Aldrich; Merck KGaA) at $37^{\circ} \mathrm{C}$ in a humidified incubator containing $5 \% \mathrm{CO}_{2}$ for enrichment. According to the aforementioned technique, sorted $\mathrm{CD}_{133}{ }^{+}$(-FITC; eBioscience, San Diego, CA, USA) CD31+ (-PE/Cy7; BioLegend) CD144 ${ }^{+}$ (-PE, BD Biosciences) and CD11b- (-APC; BioLegend) cells (EPCs) were obtained for further culture in EBM-2 medium (Lonza Group Ltd) for enrichment. All of the EPC cells were plated in a $60 \mathrm{~mm}$ cell culture dish coated with fibronectin to promote cell adhesion and growth.

Coculture of MSCs and EPCs. MSCs and EPCs were cocultured in cell number ratios of 1:1 in 6-well plates or $60 \mathrm{~mm}$ cell culture dishes. Cells were cultured in LG-DMEM without FBS at $37^{\circ} \mathrm{C}$ in a humidified incubator containing $5 \% \mathrm{CO}_{2}$ for $24 \mathrm{~h}$. Inoculation density was in accordance with experimental requirements and cells were then prepared for subsequent experiments.

Determination of IL-1 $\beta$ expression by ELISA. All of the groups: MSCs, EPCs, MSCs + EPCs, EPC-CM-MSCs and MSC-CM-EPCs, were seeded at $2 \times 10^{5}$ cells/well in 6-well plates alongside $2 \mathrm{ml}$ serum- and factor-free medium for $24 \mathrm{~h}$. We used MSC-CM to stimulate EPC cells and collected the supernatant to detect the IL-1 $\beta$ expression by ELISA kit. For the same reason, we named the EPC-CM to stimulate the MSC cells group as EPC-CM-MSC. We aim to collect the IL-1 $\beta$ expression in each group for comparison and analysis. Subsequently, supernatants were collected and centrifuged $\left(4^{\circ} \mathrm{C} ; 5,000 \mathrm{x} \mathrm{g} ; 10 \mathrm{~min}\right)$ in order to measure IL-1 $\beta$ expression using an IL-1 $\beta$ ELISA kit (cat. no. SEA563Mu; Uscn Life Sciences, Inc., Wuhan, China) according to the manufacturer's protocol.

Detection of ICAM-1 by cell immunofluorescence. Cells were plated onto coverslips ( $2 \times 10^{4}$ cells/sample), which were cultured in $6 \mathrm{~mm}$ dishes with $2 \mathrm{ml}$ corresponding medium (LG-DMEM supplemented with $10 \%$ lot-selected FBS, both from Gibco; Thermo Fisher Scientific, Inc.) for $24 \mathrm{~h}$. Subsequently, the medium was replaced with serum- and factor-free medium supplemented with IL-1 $\beta(25 \mu \mathrm{g} / \mathrm{ml})$ or p38 MAPK inhibitor SB203580 $(20 \mu \mathrm{mol} / \mathrm{ml})$, and cells were incubated for a further $24 \mathrm{~h}$. After culturing for $24 \mathrm{~h}$, the coverslips were rinsed in PBS three times and fixed with $4 \%$ paraformaldehyde for $20 \mathrm{~min}$. Subsequently, the cells were blocked in 5\% bovine serum albumin (BSA) for $30 \mathrm{~min}$ at room temperature and incubated overnight with anti-mouse ICAM-1 monoclonal 
antibodies (ab171123, 1:100) or isotype control antibody (ab81032, 1:100) (both from Abcam, Cambridge, MA, USA) at $4^{\circ} \mathrm{C}$. After rinsing in PBS three times, the cells were incubated with FITC-conjugated goat anti mouse immunoglobulin (Ig) G (cat. no. ZB2305; 1:100; OriGene Technologies, Inc., Beijing, China) in the dark for a further $1 \mathrm{~h}$. After washing, the nuclei were stained with propidium iodide (PI, $10 \mu \mathrm{g}$ / ml; cat. no. P4170; Sigma-Aldrich; Merck KGaA) solution and washed a further three times with PBS. Subsequently, $70 \%$ glycerol was used to mount the coverslips onto slides and expression was detected using a confocal laser scanning microscope (LSM 510 META; Zeiss GmbH, Jena, Germany). The experiments were performed and repeated $>3$ times.

Western blotting to detect ICAM-1 and p38 MAPK expression. Following pretreatment, the cells $\left(2 \times 10^{6}\right.$ cells/sample $)$ were washed three times with ice-cold PBS and protein samples were extracted using radioimmunoprecipitation assay buffer (500 $\mu \mathrm{l})$ with phenylmethylsulfonyl fluoride (5 $\mu \mathrm{l})$ (both from Thermo Fisher Scientific, Inc.). Protein concentration was determined using a bicinchoninic acid protein assay kit (Thermo Fisher Scientific, Inc.). Subsequently, protein samples were treated with $5 \mathrm{X}$ loading buffer $(100 \mu \mathrm{l}$; Thermo Fisher Scientific, Inc.) and heated for $8 \mathrm{~min}$ at $100^{\circ} \mathrm{C}$. Protein samples $(40 \mu \mathrm{g})$ were then separated by 10\% SDS-PAGE and were transferred onto a polyvinylidene difluoride membrane. The membrane was blocked with $5 \%$ skim milk or $5 \%$ BSA, and incubated overnight with anti-ICAM-1 (ab171123, 1:500; Abcam), anti-p38 MAPK (cat. no. \#8690; 1:1,000) and anti-p-p38 MAPK (cat. no. \#4511; 1:1,000; both from Cell Signaling Technology, Inc., Danvers, MA, USA) at $4^{\circ} \mathrm{C}$. After washing three times with Tris-buffered saline containing $0.1 \%$ Tween-20, the membrane was incubated with goat antimouse $(1: 10,000$; cat. no. ZB2305) or goat anti-rabbit $(1: 10,000$; cat. no. ZB2301) IgG horseradish peroxidase-conjugated antibodies (OriGene Technologies, Inc.) at room temperature for $2 \mathrm{~h}$ and was detected by enhanced chemiluminescence (34094; Thermo Fisher Scientific, Inc.) for $12 \mathrm{~h}$ at $4^{\circ} \mathrm{C}$. GAPDH $\left(1: 1,000 ; 12\right.$ h, $4^{\circ} \mathrm{C}$; cat. no. \#51332; Cell Signaling Technology, Inc.) was used to normalize the relative protein expression levels. The results and integrated optical density (IOD) values were analyzed by Gel-Pro Analyzer 4.0 (Media Cybernetics, Inc., Rockville, MD, USA). Experiments were performed independently and were repeated three times.

Labeling of MSCs with DAPI and EPCs with MitoTracker red. MSCs were washed three times with PBS and incubated with DAPI ( $2 \mu \mathrm{l} / \mathrm{ml}$; Sigma-Aldrich; Merck KGaA) for $30 \mathrm{~min}$ at $37^{\circ} \mathrm{C}$. Subsequently, cells were washed three times with PBS and were detected using a fluorescence microscope. The same methods were adopted to label EPCs with MitoTracker red (200 nM/ml; Thermo Fisher Scientific, Inc.).

MSCs and EPCs adhesion assay. Matrigel (BD Biosciences) was incubated at $4^{\circ} \mathrm{C}$ overnight to melt into liquid. Subsequently, a 24 -well plate was coated with Matrigel (200 $\mu \mathrm{l} /$ well) on ice and was incubated at $37^{\circ} \mathrm{C}$ for $30 \mathrm{~min}$ in a humidified incubator containing $5 \% \mathrm{CO}_{2}$ to allow the Matrigel to solidify. MSCs-DAPI $\left(5 \times 10^{4}\right.$ cells/well $)$ and EPCs-MitoTrack red $\left(5 \times 10^{4}\right.$ cells/well $)$ were seeded into the pretreated 24 -well

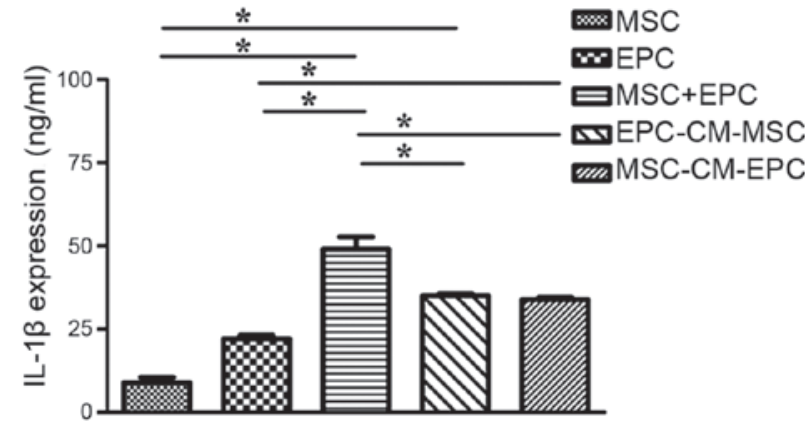

Figure 1. ELISA was used to detect the expression levels of IL-1 $\beta$ in MSCs, EPCs, MSCs + EPCs, EPC-CM-MSCs and MSC-CM-EPCs. IL- $1 \beta$ was expressed in all groups at different levels. " $\mathrm{P}<0.05$. EPCs, endothelial progenitor cells; IL-1 $\beta$, interleukin-1 $\beta$; MSCs, mesenchymal stem cells.

plate with EPCs culture medium (1 ml ; EBM-2 medium; cat. no. CC-3156; Lonza Group Ltd.) supplemented with antiICAM-1 neutralizing antibody (ab171123, 1:50; Abcam), IL-1 $\beta$ (030447, $25 \mu \mathrm{g} / \mathrm{ml}$; PeproTech, Inc., Rocky Hill, NJ, USA) or SB203580 (cat. no. S8307, lot. no. 104M4605v; $20 \mu \mathrm{mol} / \mathrm{ml}$; Sigma-Aldrich). After culturing for $6-8 \mathrm{~h}$ at $37^{\circ} \mathrm{C}$ in a humidified incubator containing $5 \% \mathrm{CO}_{2}$, the plates were randomly imaged under a fluorescence microscope.

Statistics analysis. Data are expressed as the means \pm standard deviation. SPSS 17.0 statistical software (SPSS, Inc., Chicago, IL, USA) was used to analyze results. Statistical significance of group data was assessed using one-way analysis of variance (ANOVA) followed by SNK post hoc multiple comparisons test. $\mathrm{P}<0.05$ was considered to indicate a statistically significant difference.

\section{Results}

IL-1 $\beta$ expression in culture medium. To determine the expression levels of IL-1 $\beta$ in MSCs, EPCs, MSCs + EPCs, EPC-CM-MSCs and MSC-CM-EPCs (Fig. 1), the groups were seeded into 6 -well plates $\left(2 \times 10^{5}\right.$ cells/well) and treated with serum- and factor-free medium for $24 \mathrm{~h}$. The results indicated that both MSCs and EPCs can secrete IL-1 $\beta$, and in the MSCs + EPCs $(49.13 \pm 6.21 \mathrm{ng} / \mathrm{ml})$ group, IL-1 $\beta$ expression was higher than in the MSCs group $(8.96 \pm 2.70 \mathrm{ng} / \mathrm{ml}, \mathrm{P}<0.05)$ and the EPCs group $(22.14 \pm 1.83 \mathrm{ng} / \mathrm{ml}, \mathrm{P}<0.05)$. In addition, in the EPC-CMMSCs group $(35.02 \pm 1.19 \mathrm{ng} / \mathrm{ml})$ and the MSC-CM-EPCs group $(33.85 \pm 1.37 \mathrm{ng} / \mathrm{ml}) \mathrm{IL}-1 \beta$ expression was higher compared with in the MSCs group $(8.96 \pm 2.70 \mathrm{ng} / \mathrm{ml}, \mathrm{P}<0.05)$ and the EPCs group $(22.14 \pm 1.83 \mathrm{ng} / \mathrm{ml}, \mathrm{P}<0.05)$, but not compared with in the MSCs + EPCs group $(49.13 \pm 6.21 \mathrm{ng} / \mathrm{ml}, \mathrm{P}>0.05)$.

Immunofluorescence detection of ICAM-1 expression. Cells were seeded on coverslips $\left(2 \times 10^{4}\right.$ cells/sample) and were cultured in $6 \mathrm{~mm}$ dishes with $2 \mathrm{ml}$ corresponding medium for $24 \mathrm{~h}$. Subsequently, medium was replaced with serumand factor-free medium supplemented with IL-1 $\beta(25 \mu \mathrm{g} / \mathrm{ml})$ or p38 MAPK inhibitor SB203580 $(20 \mu \mathrm{mol} / \mathrm{ml})$ for $24 \mathrm{~h}$. ICAM-1 expression was then detected by immunofluorescence (Fig. 2). The results indicated that MSCs and EPCs are able to express low levels of ICAM-1; however, in the MSCs + EPCs 


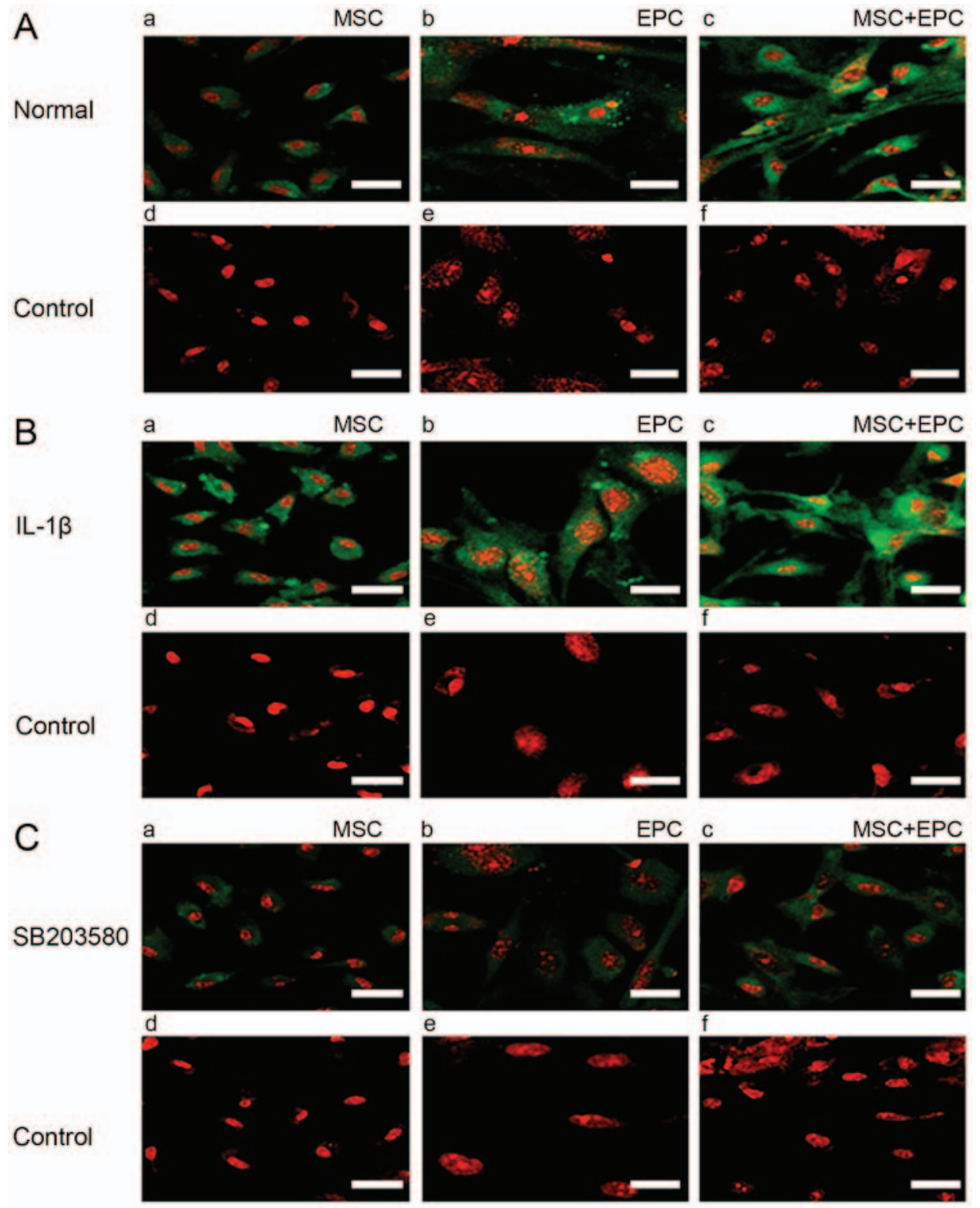

Figure 2. Immunofluorescence detection of ICAM-1 expression. (A) (a-c) Expression of ICAM-1 (FITC) in MSCs, EPCs and MSCs + EPCs normally cultured in vitro, as determined by cell immunofluorescence under a laser confocal microscope. (d-f) Mouse IgG control (FITC) staining. (B) (a-c) Expression of ICAM-1 (FITC) in MSCs, EPCs and MSCs + EPCs treated with IL-1 $3(25 \mu \mathrm{g} / \mathrm{ml})$ in vitro. (d-f) Mouse IgG control (FITC) staining. (C) (a-c) Expression of ICAM-1 (FITC) in MSCs, EPCs and MSCs + EPCs treated with the p38 mitogen-activated protein kinase inhibitor SB203580 (20 $\mu \mathrm{mol} / \mathrm{ml})$ in vitro. (d-f) Mouse IgG control (FITC) staining. Scale bar, $5 \mu \mathrm{m}$. EPCs, endothelial progenitor cells; FITC, fluorescein isothiocyanate; ICAM-1, intercellular adhesion molecule-1; IgG, immunoglobulin G; IL-1 $\beta$, interleukin-1 $\beta$; MSCs, mesenchymal stem cells.

group the expression of ICAM-1 was increased. All of the IL-1 $\beta$-treated groups (Fig. 2B) exhibited increased ICAM-1 expression compared with in the normal (Fig. 2A) and SB203580 groups (Fig. 2C). ICAM-1 expression was lowest in the SB203580 groups compared with in the untreated and IL-1 $\beta$-treated groups.

Western blotting to detect the expression levels of ICAM-1 and 338 MAPK. The protein expression levels of ICAM-1 and p38 MAPK were detected in MSCs, EPCs and MSCs + EPCs using western blotting (Fig. 3A). The relative ICAM-1/GAPDH IOD (Fig. 3B) and p-p38 MAPK/total-p38 MAPK IOD values (Fig. 3C) were then determined for statistical analysis. Normally cultured MSCs + EPCs $(0.21 \pm 0.01, \mathrm{P}<0.05)$ exhibited increased ICAM-1 expression compared with in the corresponding MSCs group $(0.11 \pm 0.02, \mathrm{P}<0.05)$ and EPCs group $(0.11 \pm 0.02, \mathrm{P}<0.05)$; however, there was no significant difference between the MSCs and EPCs groups. In the IL-1 $\beta$-stimulated MSCs + EPCs group $(0.38 \pm 0.02, \mathrm{P}<0.05)$ the expression levels of ICAM-1 were increased compared with in the corresponding MSCs group $(0.23 \pm 0.02, \mathrm{P}<0.05)$ and EPCs group $(0.25 \pm 0.02, \mathrm{P}<0.05)$. The p38 MAPK inhibitor SB203580-treated MSCs + EPCs group $(0.10 \pm 0.02, \mathrm{P}<0.05)$ exhibited increased ICAM-1 expression compared with in the corresponding MSCs group $(0.05 \pm 0.01, \mathrm{P}<0.05)$ and EPCs group $(0.05 \pm 0.01, \mathrm{P}<0.05)$. ICAM-1 expression was increased in the IL-1 $\beta$-stimulated groups $(\mathrm{P}<0.05)$, but was decreased in the SB203580-stimulated groups $(\mathrm{P}<0.05)$ compared with in the normal groups. Normally cultured MSCs + EPCs $(0.52 \pm 0.02$, $\mathrm{P}<0.05$ ) exhibited increased p-p38 MAPK expression compared 


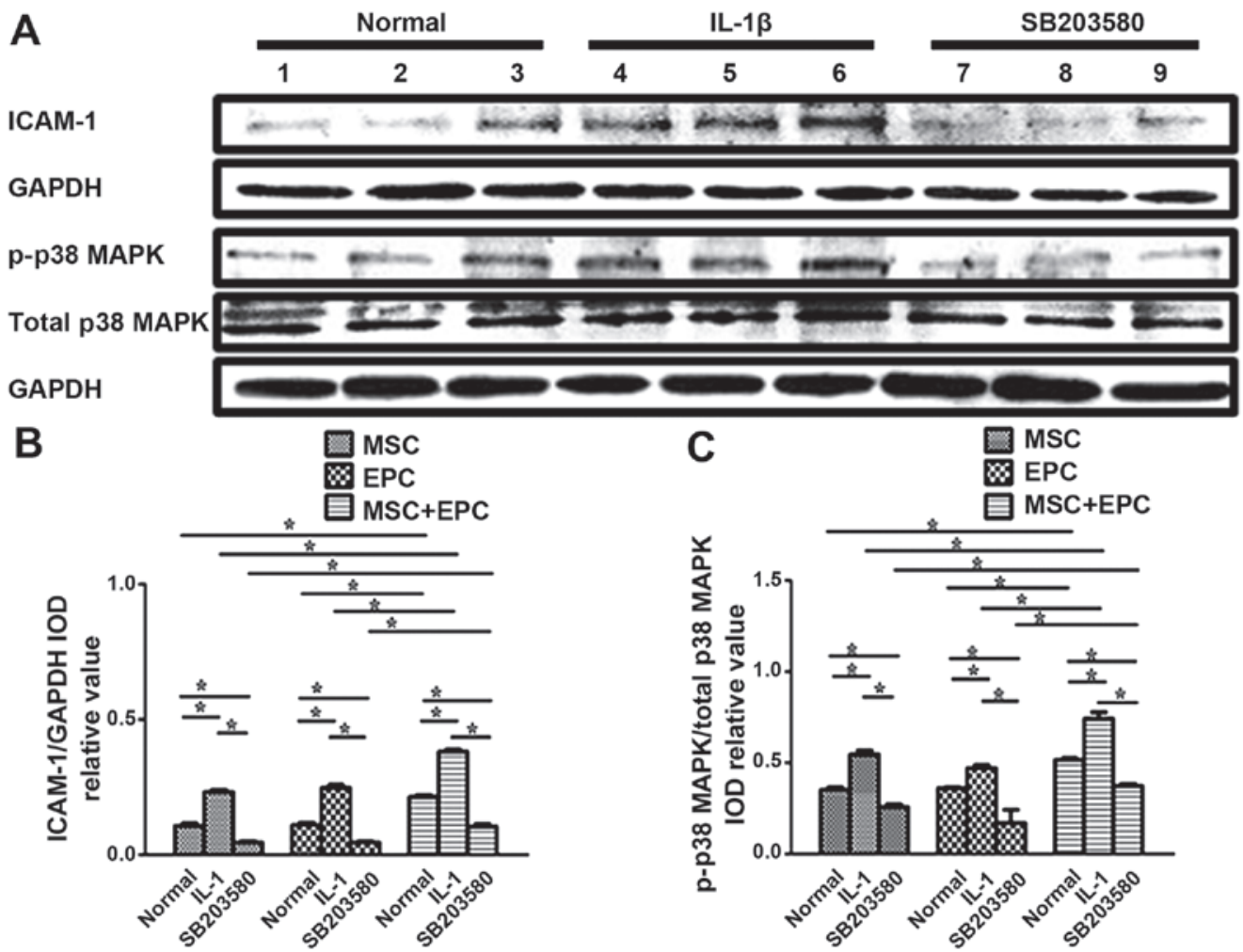

Figure 3. (A) Western blot analysis of ICAM-1, GAPDH, p-p38 MAPK and total p38 MAPK in MSCs, EPCs and MSCs + EPCs, with or without IL-18 $(25 \mu \mathrm{g} / \mathrm{ml})$ or p38 MAPK inhibitor SB203580 (20 $\mu \mathrm{mol} / \mathrm{ml})$ treatment. Lanes 1-3, normally cultured MSCs, EPCs and MSCs + EPCs groups, respectively; lanes 4-6, IL-1 $\beta(25 \mu \mathrm{g} / \mathrm{ml})$-stimulated MSCs, EPCs and MSCs + EPCs groups, respectively; lanes 7-9, p38 MAPK inhibitor SB203580 (20 $\mu \mathrm{mol} / \mathrm{ml})$-stimulated MSCs, EPCs and MSCs + EPCs groups, respectively. (B) ICAM-1/GAPDH and (C) p-p38 MAPK/total-p38 MAPK IOD relative values were determined Data are presented as the means \pm standard deviation of three independent experiments. " $\mathrm{P}<0.05$. EPCs, endothelial progenitor cells; ICAM-1, intercellular adhesion molecule-1; IL-1 $\beta$, interleukin-1 $\beta$; IOD, integrated optical density; MAPK, mitogen-activated protein kinase; MSCs, mesenchymal stem cells.

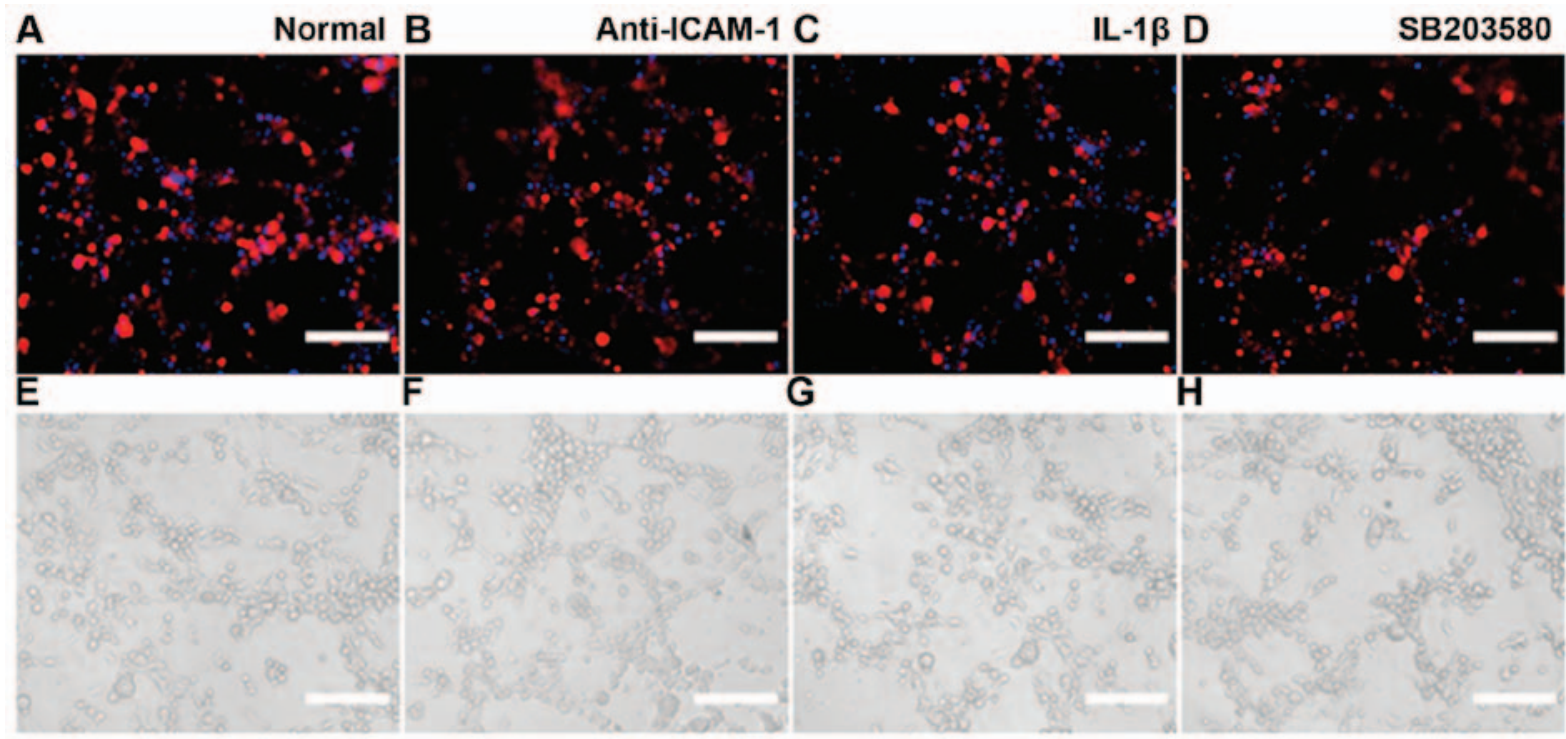

Figure 4. Adhesion of MSCs (DAPI, blue staining) and EPCs (Mitrotrack red, red staining) was detected in Matrigel-coated plates. (A) Adhesion of normally cultured MSCs and EPCs. Adhesion of MSCs and EPCs treated with (B) anti-ICAM-1 neutralizing antibody, (C) IL- $1 \beta$ (25 $\mu \mathrm{g} / \mathrm{ml})$ and (D) p38 mitogen-activated protein kinase inhibitor SB203580 $(20 \mu \mathrm{mol} / \mathrm{ml})$. (E-H) White-light image of (A-D), respectively. Scale bar, $100 \mu \mathrm{m}$. EPCs, endothelial progenitor cells; ICAM-1, intercellular adhesion molecule-1; IL-1 $\beta$, interleukin-1 $\beta$; MSCs, mesenchymal stem cells.

with in the corresponding MSCs group $(0.35 \pm 0.02, \mathrm{P}<0.05)$ and EPCs group $(0.36 \pm 0.01, \mathrm{P}<0.05)$; however there was no significant difference between the MSCs and EPCs groups. In the IL-1 $\beta$-stimulated MSCs + EPCs group $(0.74 \pm 0.06, \mathrm{P}<0.05)$, the expression levels of p-p38 MAPK were increased compared with in the corresponding MSCs group $(0.54 \pm 0.04, \mathrm{P}<0.05)$ and EPCs group $(0.47 \pm 0.03, \mathrm{P}<0.05)$. The p38 MAPK inhibitor SB203580-stimulated MSCs + EPCs group $(0.37 \pm 0.02, \mathrm{P}<0.05)$ 
exhibited increased p-p38 MAPK expression compared with in the corresponding MSCs group $(0.26 \pm 0.03, \mathrm{P}<0.05)$ and EPCs group $(0.17 \pm 0.01, \mathrm{P}<0.05)$. The expression levels of p-p38 MAPK were increased following IL-1 $\beta$ treatment $(\mathrm{P}<0.05)$; however, they were decreased following treatment with the p38 MAPK inhibitor SB203580 ( $<<0.05)$, respectively. The expression levels of total p38 MAPK remained constant in all groups following various treatments.

MSCs and EPCs adhesion assay. MSCs were labeled with DAPI and EPCs were labeled with MitoTracker red. MSCs-DAPI and EPCs-Mitotrack-red were cocultured in Matrigel-coated 24-well plates $\left(5 \times 10^{4}\right.$ cells/well, $\left.1: 1\right)$ with EPCs culture medium supplemented with anti-ICAM-1 neutralizing antibody (), IL-1 $\beta(25 \mu \mathrm{g} / \mathrm{ml})$ or p38 MAPK inhibitor SB203580 $(20 \mu \mathrm{mol} /$ $\mathrm{ml})$. Subsequently, the cells were cultured for $6-8 \mathrm{~h}$ at $37^{\circ} \mathrm{C}$ in a humidified incubator containing $5 \% \mathrm{CO}_{2}$. The results indicated that treatment with anti-ICAM-1 neutralizing antibody or p38 MAPK inhibitor SB203580 resulted in a decrease in adhesion between MSCs and EPCs; however, supplementation with IL-1 $\beta$ markedly increased adhesion (Fig. 4).

\section{Discussion}

The microenvironment surrounding stem cells, which is also known as the stem-cell niche, is composed of adjacent cells, extracellular matrix and adhesive molecules, and regulates stem cell self-renewal and differentiation. The stem-cell niche also aids regulation of cell fate, and is an interactive structural unit that functions via the cross-talk of key signaling and molecular factors (4-6). The functions of the stem-cell niche are reliant on adhesion molecules, which anchor stem cells in the niche and regulate communication with surrounding cells or various molecules.

As previously reported, EPCs likely interact with MSCs in the BM stem-cell niche (7); interactions between EPCs and MSCs may enhance neovascularization and bone regeneration (11-14). Therefore, focusing on the adhesion of MSCs and EPCs may provide information regarding clinical bone injury and vascular bone regeneration. However, the underlying mechanism that mediates the adhesion of MSCs and EPCs remains unclear. ICAM-1 is an important adhesion molecule and a member of the immunoglobulin supergene family, which participates in cell-cell and cell-matrix adhesive interactions, including those between tumor cells, endothelial cells, T cells, leukocytes and vascular cells (32-34). Furthermore, adhesion may be decreased by suppressing ICAM-1 expression. As an important adhesion molecule, previous studies have suggested that ICAM-1 may regulate IL-1 $\beta$ (19-21), tumor necrosis factor- $\alpha$ (35) and lipopolysaccharide (36). The present study focused on the stimulatory effects of IL-1 $\beta$ on ICAM-1, since IL- $1 \beta$ is an important inflammatory mediator, which not only affects nearly every cell type and interacts with numerous cytokines and small mediator molecules, but also participates in various physiological functions and diseases, including clinical bone injury (22-25) and vascular injury $(26,27)$.

The present study demonstrated that both MSCs and EPCs could express low levels of ICAM-1; however, coculturing MSCs with EPCs increased ICAM-1 expression, particularly following treatment with IL-1 $\beta$; however, treatment with the p38 MAPK inhibitor SB203580 inhibited ICAM-1 expression. These results indicated that IL-1 $\beta$ may activate the p38 MAPK pathway. Furthermore, cocultured MSCs and EPCs were seeded in Matrigel-coated plates; the results demonstrated that supplementation with anti-ICAM-1 neutralizing antibody or SB203580 effectively inhibited adhesion between MSCs and EPCs, whereas supplementation with IL-1 $\beta$ had the opposite effect. These results highlighted the importance of ICAM-1 for the adhesion between MSCs and EPCs, and this may be regulated by IL-1 $\beta$ through the p38 MAPK signaling pathway. However, at present, it remains unknown as to whether MSCs regulate EPCs function, or whether EPCs regulate MSCs function; potential joint action may serve an important role in the stem-cell niche. Previously, our laboratory indicated that EPCs promoted osteogenic differentiation of MSCs in a paracrine manner (37). Burlacu et al reported that MSCs may promote angiogenesis of EPCs in a paracrine manner (13). Furthermore, Ern et al demonstrated that EPCs and MSCs can secrete osteogenic or angiogenic factors to promote proliferation and differentiation in a paracrine manner (38). Therefore, the present study hypothesized that paracrine signaling is critical for the regulation of the effects of MSCs and EPCs coculture. The present study indicated that MSCs and EPCs could secrete IL-1 $\beta$, whereas coculturing MSCs with EPCs enhanced the secretion of IL-1 $\beta$. In addition, EPC-CM-MSCs and MSC-CMEPCs groups exhibited higher levels of IL-1 $\beta$ compared with MSC-CM and EPC-CM; however they were not higher than in the MSCs + EPCs group. These results provided convincing evidence to explain the increased expression of ICAM-1 in cocultured MSCs and EPCs.

In conclusion, the present study demonstrated that IL- $1 \beta$ may induce ICAM-1 expression, thus enhancing the cohesion between MSCs and EPCs via the p38 MAPK signaling pathway. These findings provide effective evidence to support and explain previous findings regarding the adhesion of MSCs and EPCs. In addition, the present study provided a theoretical basis for further stem-cell niche transplantation to increase understanding regarding the function of MSCs and for subsequent experimental research. However, the factors that regulate secretion of IL-1 $\beta$ remain unclear; our future studies aim to focus on this, and to conduct further in vitro experiments regarding clinical application (clinical bone injury treatment, vascular bone regeneration, tissue repair and immune disorder therapy).

\section{Acknowledgements}

The present study was supported by grants from the National Natural Science Foundation of China (grant nos. 81760570 and 31271458), the Science and Technology program of Xinjiang Production and Construction Corps (grant no. 2014AB047), the Scientific Research Foundation for the Returned Overseas Chinese Scholars, Ministry of Human Resources and Social Security of the People's Republic of China (grant no. RSLX201201) and the Shihezi University Youth Science and Technology Research and Development program, basis and application research project (grant no. 20142RKXYQ20).

\section{Competing interests}

The authors declare there is no competing interest. 


\section{References}

1. Friedenstein AJ, Chailakhjan RK and Lalykina KS: The development of fibroblast colonies in monolayer cultures of guinea-pig bone marrow and spleen cells. Cell Tissue Kinet 3: 393-403, 1970.

2. Pittenger MF, Mackay AM, Beck SC, Jaiswal RK, Douglas R, Mosca JD, Moorman MA, Simonetti DW, Craig S and Marshak DR: Multilineage potential of adult human mesenchymal stem cells. Science 284: 143-147, 1999.

3. Jiang Y, Jahagirdar BN, Reinhardt RL, Schwartz RE, Keene CD, Ortiz-Gonzalez XR, Reyes M, Lenvik T, Lund T, Blackstad M, et al: Pluripotency of mesenchymal stem cells derived from adult marrow. Nature 418: 41-49, 2002.

4. Moore KA and Elmendorf SC: Propagule vs. niche limitation: Untangling the mechanisms behind plant species' distributions. Ecol Lett 9: 797-804, 2006.

5. Spradling A, Drummond-Barbosa D and Kai T: Stem cells find their niche. Nature 414: 98-104, 2001.

6. Moore KA and Lemischka IR: Stem cells and their niches. Science 311: 1880-1885, 2006.

7. Zhang H, Xian L, Lin Z, Yang C, Zhang M, Feng W, Peng X, Chen $\mathrm{X}$ and $\mathrm{Wu} \mathrm{X}$ : Endothelial progenitor cells as a possible component of stem cell niche to promote self-renewal of mesenchymal stem cells. Mol Cell Biochem 397: 235-243, 2014.

8. Asahara T, Murohara T, Sullivan A, Silver M, van der Zee R, Li T, Witzenbichler B, Schatteman G and Isner JM: Isolation of putative progenitor endothelial cells for angiogenesis. Science 275: 964-967, 1997.

9. Kalka C, Masuda H, Takahashi T, Kalka-Moll WM, Silver M, Kearney M, Li T, Isner JM and Asahara T: Transplantation of ex vivo expanded endothelial progenitor cells for therapeutic neovascularization. Proc Natl Acad Sci USA 97: 3422-3427, 2000.

10. Minamino T, Miyauchi H, Yoshida T, Ishida Y, Yoshida H and Komuro I: Endothelial cell senescence in human atherosclerosis: Role of telomere in endothelial dysfunction. Circulation 105: 1541$1544,2002$.

11. Grellier M, Bordenave L and Amédée J: Cell-to-cell communication between osteogenic and endothelial lineages: Implications for tissue engineering. Trends Biotechnol 27: 562-571, 2009.

12. Fu WL, Xiang Z, Huang FG, Gu ZP, Yu XX, Cen SQ, Zhong G, Duan $X$ and Liu M: Coculture of peripheral blood-derived mesenchymal stem cells and endothelial progenitor cells on strontium-doped calcium polyphosphate scaffolds to generate vascularized engineered bone. Tissue Eng Part A 21: 948-959, 2015.

13. Burlacu A, Grigorescu G, Rosca AM, Preda MB and Simionescu M: Factors secreted by mesenchymal stem cells and endothelial progenitor cells have complementary effects on angiogenesis in vitro. Stem Cells Dev 22: 643-653, 2013.

14. Zigdon-Giladi H, Bick T, Lewinson D and Machtei EE: Co-transplantation of endothelial progenitor cells and mesenchymal stem cells promote neovascularization and bone regeneration. Clin Implant Dent Relat Res 17: 353-359, 2015.

15. Zuckerman LA, Pullen L and Miller J: Functional consequences of costimulation by ICAM-1 on IL-2 gene expression and T cell activation. J Immunol 160: 3259-3268, 1998

16. Agarwal SK and Brenner MB: Role of adhesion molecules in synovial inflammation. Curr Opin Rheumatol 18: 268-276, 2006.

17. Shaw SK, Ma S, Kim MB, Rao RM, Hartman CU, Froio RM, Yang L, Jones T, Liu Y, Nusrat A, et al: Coordinated redistribution of leukocyte LFA-1 and endothelial cell ICAM-1 accompany neutrophil transmigration. J Exp Med 200: 1571-1580, 2004.

18. Sumagin R and Sarelius IH: Intercellular adhesion molecule-1 enrichment near tricellular endothelial junctions is preferentially associated with leukocyte transmigration and signals for reorganization of these junctions to accommodate leukocyte passage. J Immunol 184: 5242-5252, 2010.

19. Chang MC, Hung HP, Lin LD, Shyu YC, Wang TM, Lin HJ, Chan CP, Huang CC and Jeng JH: Effect of interleukin-1 $\beta$ on ICAM-1 expression of dental pulp cells: Role of PI3K/Akt, MEK/ERK, and cyclooxygenase. Clin Oral Investig 19: 117-126, 2015.

20. Shikama Y, Aki N, Hata A, Nishimura M, Oyadomari S and Funaki M: Palmitate-stimulated monocytes induce adhesion molecule expression in endothelial cells via IL-1 signaling pathway. J Cell Physiol 230: 732-742, 2015.

21. Yamagami H, Yamagami S, Inoki T, Amano S and Miyata K: The effects of proinflammatory cytokines on cytokine-chemokine gene expression profiles in the human corneal endothelium. Invest Ophthalmol Vis Sci 44: 514-520, 2003.
22. Horton JE, Raisz LG, Simmons HA, Oppenheim JJ and Mergenhagen SE: Bone resorbing activity in supernatant fluid from cultured human peripheral blood leukocytes. Science 177: 793-795, 1972.

23. DewhirstFE, Stashenko PP, Mole JE and Tsurumachi T: Purification and partial sequence of human osteoclast-activating factor: Identity with interleukin 1 beta. J Immunol 135: 2562-2568, 1985.

24. Stashenko P, Dewhirst FE, Peros WJ, Kent RL and Ago JM: Synergistic interactions between interleukin 1, tumor necrosis factor, and lymphotoxin in bone resorption. J Immunol 138: 1464-1468, 1987.

25. Xiong Y, Donovan KA, Kline MP, Gornet MK, Moon-Tasson LL, Lacy MQ, Dispenzieri A, Gertz MA, Greipp PR and Lust JA: Identification of two groups of smoldering multiple myeloma patients who are either high or low producers of interleukin-1. J Interferon Cytokine Res 26: 83-95, 2006.

26. Zhang R, Jiang F, Chen CS, Wang T, Feng J, Tao T and Qin X: Serum levels of IL-1 $\beta$, IL-6, TGF- $\beta$, and MMP-9 in patients undergoing carotid artery stenting and regulation of MMP-9 in a new in vitro model of THP-1 cells activated by stenting. Mediators Inflamm 2015: 956082, 2015.

27. Alfaidi M, Wilson H, Daigneault M, Burnett A, Ridger V, Chamberlain $\mathbf{J}$ and Francis S: Neutrophil elastase promotes interleukin-1 $\beta$ secretion from human coronary endothelium. J Biol Chem 290: 24067-24078, 2015.

28. Wuyts WA, Vanaudenaerde BM, Dupont LJ, Demedts MG and Verleden GM: Involvement of p38 MAPK, JNK, p42/p44 ERK and NF-kappaB in IL-1 $\beta$-induced chemokine release in human airway smooth muscle cells. Respir Med 97: 811-817, 2003.

29. Hsu WY, Chao YW, Tsai YL, Lien CC, Chang CF, Deng MC, Ho LT, Kwok CF and Juan CC: Resistin induces monocyteendothelial cell adhesion by increasing ICAM-1 and VCAM-1 expression in endothelial cells via p38 MAPK-dependent pathway. J Cell Physiol 226: 2181-2188, 2011.

30. Liang B, Wang X, Zhang N, Yang H, Bai R, Liu M, Bian Y, $\mathrm{Xiao} \mathrm{C}$ and Yang Z: Angiotensin-(1-7) attenuates angiotensin II-induced ICAM-1, VCAM-1, and MCP-1 expression via the MAS Receptor through suppression of $\mathrm{p} 38$ and NF- $\mathrm{kB}$ pathways in HUVECs. Cell Physiol Biochem 35: 2472-2482, 2015.

31. Lee SJ, Drabik K, Van Wagoner NJ, Lee S, Choi C, Dong Y and Benveniste EN: ICAM-1-induced expression of proinflammatory cytokines in astrocytes: Involvement of extracellular signalregulated kinase and p38 mitogen-activated protein kinase pathways. J Immunol 165: 4658-4666, 2000.

32. Park JS, Kim KM, Kim MH, Chang HJ, Baek MK, Kim SM and Jung YD: Resveratrol inhibits tumor cell adhesion to endothelial cells by blocking ICAM-1 expression. Anticancer Res 29: 355-362, 2009.

33. Deane JA, Abeynaike LD, Norman MU, Wee JL, Kitching AR, Kubes $\mathrm{P}$ and Hickey MJ: Endogenous regulatory T cells adhere in inflamed dermal vessels via ICAM-1: Association with regulation of effector leukocyte adhesion. J Immunol 188: 2179-2188, 2012.

34. Lacal PM, Petrillo MG, Ruffini F, Muzi A, Bianchini R, Ronchetti S, Migliorati G, Riccardi C, Graziani G and Nocentini G: Glucocorticoid-induced tumor necrosis factor receptor familyrelated ligand triggering upregulates vascular cell adhesion molecule- 1 and intercellular adhesion molecule- 1 and promotes leukocyte adhesion. J Pharmacol Exp Ther 347: 164-172, 2013.

35. Kim KH, Lee EN, Park JK, Lee JR, Kim JH, Choi HJ, Kim BS, Lee HW, Lee KS and Yoon S: Curcumin attenuates TNF- $\alpha-$ induced expression of intercellular adhesion molecule-1, vascular cell adhesion molecule-1 and proinflammatory cytokines in human endometriotic stromal cells. Phytother Res 26: 1037-1047, 2012.

36. Park GS and Kim JH: LPS Up-regulates ICAM-1 expression in breast cancer cells by stimulating a MyD88-BLT2-ERK-linked cascade, which promotes adhesion to monocytes. Mol Cells 38: 821-828, 2015.

37. Zhang M, Zhang H, Feng W, Wang Y, Yin S, Chen X and Wu X: Endothelial progenitor cells promote osteogenic differentiation of marrow stromal cells in a paracrine manner. Zhonghua Yi Xue Za Zhi 95: 1253-1257, 2015 (In Chinese).

38. Ern C, Krump-Konvalinkova V, Docheva D, Schindler S, Rossmann O, Böcker W, Mutschler W and Schieker M: Interactions of human endothelial and multipotent mesenchymal stem cells in cocultures. Open Biomed Eng J 4: 190-198, 2010.

This work is licensed under a Creative Commons Attribution-NonCommercial-NoDerivatives 4.0 International (CC BY-NC-ND 4.0) License. 